\title{
TEMPORAL STABILITY OF TOTAL ORGANIC CARBON OF SOILS UNDER DIFFERENT USES IN THE CAATINGA BIOME ${ }^{1}$
}

\author{
VALÉRIA RAMOS LOURENÇO ${ }^{2}$, CARLOS ALEXANDRE GOMES COSTA ${ }^{3 *}$, ALDÊNIA MENDES MASCENA DE \\ ALMEIDA $^{4}$, FRANCISCO JAIRO SOARES PEREIRA ${ }^{3}$, ADÃO BARROS DE MORAIS ${ }^{3}$
}

\begin{abstract}
The objective of this work was to evaluate the temporal stability of total organic carbon (TOC) of soils under different uses in areas with Caatinga vegetation. The experiment was conducted in an experimental farm that encompasses a watershed in the Curu River Valley, in Pentecoste, state of Ceara, Brazil. Soil samples were collected in two areas with Caatinga vegetation under different uses - one with a 35-year preserved area (CP35) and one with a 30-year pasture area (CR30) - and the sampling points were distributed using a $30 \times 30 \mathrm{~m}$ uniform grid. Soil samples of the 0-0.2 m layer were collected between February 2016 and April 2017 to determine TOC; and nonparametric Spearman's correlation, mean relative difference (MRD), and temporal stability index (TSI) tests were applied to evaluate TOC stability. The Spearman's test showed a higher correlation between collection dates for CR30 than for CP35. The DRM showed more points with relative differences approaching zero for $\mathrm{CP} 35$, and more points with lower standard deviation for CR30. The TSI indicated a greater number of points to be used for CR30 because they have better temporal stability. Therefore, the TOC of the CR30 has better temporal stability than that of the CP35, presenting TSI of approximately 1.5 -fold that of the CP35. The thinning of the vegetation in CR30 homogenized the soil TOC, whereas the fallow area, which were preserved, had greater heterogeneity.
\end{abstract}

Keywords: Soil organic matter. Semiarid. Soil management. Biomass contribution.

\section{ESTABILIDADE TEMPORAL DO CARBONO ORGÂNICO TOTAL DO SOLO EM DIFERENTES CONDIÇÕES DE MANEJO DA CAATINGA}

\begin{abstract}
RESUMO - Objetivou-se com o presente trabalho avaliar a estabilidade temporal do Carbono Orgânico Total do Solo (COT) sob diferentes condições de manejo da Caatinga. O experimento foi realizado na Micro Bacia Experimental do Vale do Curu, localizada no município de Pentecoste-CE. As amostragens foram realizadas em duas parcelas de Caatinga sendo a primeira um estrato em preservação há 35 anos (CP35), e a segunda em uma área de raleio há 30 anos (CR30), os pontos amostrais foram distribuídos em uma malha uniforme de $30 \times 30 \mathrm{~m}$. Foram realizadas coletas entre fevereiro de 2016 a abril de 2017 na profundidade de $0-0,2 \mathrm{~m}$. O solo foi acondicionado e posteriormente analisado para a determinação do COT, em seguida aplicaram-se os testes não paramétricos de Spearman, Diferença Relativa Média (DRM) e o Índice de Estabilidade Temporal (IET) para a avaliação da estabilidade do COT. Observou-se uma maior correlação entre datas de coletas para a parcela CR30 em comparação com a CP35 por meio do teste de Spearman. A DRM da CP35 apresentou mais pontos com diferença relativa que se aproximam de zero, enquanto CR30 apresentou mais pontos com menor desvio padrão. Quando se aplicou o IET à CR30 apresentou um maior número de pontos indicados para serem utilizados por possuírem melhor estabilidade temporal. Portanto, pode-se concluir que a Caatinga raleada dispõe de maior estabilidade temporal que a Caatinga em preservação com valores do Índices de Estabilidade Temporal cerca de 1,5 vezes maior. O raleamento da vegetação promove homogeneização do Carbono Orgânico Total no Solo (COT), enquanto o pousio, característico manejo de preservação, maior heterogeneidade.
\end{abstract}

Palavras chave: Matéria orgânica do solo. Semiárido. Manejo do solo. Aporte de biomassa.

\footnotetext{
*Corresponding author

${ }^{1}$ Received for publication in 10/04/2017; accepted in 04/08/2019.

Paper extracted from the scientific initiation work of the first author.

${ }^{2}$ Department of Soils and plant nutrition, Universidade Federal de Viçosa, Viçosa, MG, Brazil; ramos.valeria74@yahoo.com - ORCID: 0000-0001-9662-5918.

${ }^{3}$ Department of Agricultural Engineering, Universidade Federal do Ceará, Fortaleza, CE, Brazil; costacag@gmail.com - ORCID: 00000002-3191-8581, jairosp10@gmail.com - ORCID: 0000-0002-6934-0295, adaoufc2014@outlook.com - ORCID: 0000-0002-2005-8301.

${ }^{4}$ Department of Soil Science, Universidade Federal do Ceará, Fortaleza, CE, Brazil; ald_m_@hotmail.com - ORCID: 0000-0003-09291513 .
}

Rev. Caatinga, Mossoró, v. 32, n. 3, p. 760 - 768, jul. - set., 2019 


\section{INTRODUCTION}

The variability of the soil total organic carbon (TOC) is due to the soil constant losses, contributions, and exchanges of carbon with other systems, mainly with vegetation and atmosphere. Determining soil carbon stocks and their spatiotemporal distribution is important for understanding their dynamics and assists in developing strategies to mitigate global warming effects (VENTERIS et al., 2004; HOFFMANN et al., 2012).

Soil carbon stock is affected by several factors, such as vegetation, climate, topography, and soil type. In addition, the soil management system is strongly correlated with the carbon dynamics and stock in the edaphic system (LI et al., 2010; WANG et al., 2012). Therefore, studying the TOC of different biomes is necessary to better represent its dynamics in the soil.

Caatinga is a complex plant system in Brazil; its geomorphological and geological origin generated several soil types, which vary within small distances (SAMPAIO, 1995). The management systems adopted in this biome, which search for increases in crop productivity, cause pressures on this biome; for example, managements of pastures, and removal of vegetation for firewood and coal productions. Losses begin with deforestation and substitution of vegetation by others species of different size and ecophysiology, modifying biogeochemical cycles in the biome, including carbon (SAMPAIO et al., 2005; BARRETO, 2010).

Therefore, studies on TOC dynamics are needed, considering different types and managements of soil; thus, techniques and methodologies have been developed for this purpose, such as soil digital mapping (MARTIN et al., 2011; WIESMEIER et al., 2014), TOC determination through spectroradiometry (FIORIO et al., 2010; GENÚ; DEMATTÊ, 2012), and adaptation of methods (MU et al., 2014).

The temporal stability analysis (TS) proposed by Vachaud et al. (1985) has been widely used to evaluate soil moisture conditions (COPPOLA et al., 2011; IBRAHIM; HUGGINS, 2011; GAO; SHAO, 2012; COSTA et al., 2013), however, few studies applying this method evaluate the stability of other soil parameters, such as TOC. TS is a constant association between spatial location and statistical data of a given variable over time (VAN WESENBEECK; KASHANOSKI, 1988). This technique allows the identification of points that determine the average evolution of the studied variable in the field, thus reducing some difficulties of conventional analyses such, as high costs and problems with logistics due to the large number of samples.

Considering the scarcity of data referring to the application of the method in TOC evaluation and the need for studies on its dynamics in the Caatinga biome, the objective of this work was to evaluate the temporal stability of the soil TOC in areas with Caatinga vegetation under different uses.

\section{MATERIAL AND METHODS}

\section{Study area}

The experiment was conducted in an experimental farm of the Federal University of Ceará (UFC) that encompasses a watershed in the Curu River Valley, in Pentecoste, Ceará state , Brazil $\left(3^{\circ}\right.$ $4^{\prime} \mathrm{S}, 39^{\circ} 16^{\prime} \mathrm{W}$ ) (Figure 1).

The region presents an average rainfall of 782 mm year ${ }^{-1}$ (ALMEIDA et al., 2016) and a potential evapotranspiration of $2000 \mathrm{~mm}$ year $^{-1}$, which cause water deficits throughout the year. According to the Koppen classification, it has a BSw'h' semiarid climate, with irregular precipitations and two welldefined climate seasons (FREITAS et al., 2011).

The soils found in the region (Figure 1) are Ustorthents (RL), Ustalfs (TCo) and Ustults (PVA); Ustorthents and Ustalfs are characterized by low depth and low action of pedogenetic processes, resulting in absence of a defined diagnostic B horizon in the case of the Ustorthents (SANTOS et al., 2018). The experiment was carried out in a Ustorthents of average depth of $0.3 \mathrm{~m}$.

Soil samples were collected in two areas with Caatinga vegetation under different uses - one with a preserved area of Caatinga vegetation for more than 35 years (CP35), and one area of Caatinga vegetation that had been thinned by sheep grazing for 30 years.

\section{Soil sampling and laboratory analysis}

Nine collection points, distributed in a $30 \times 30$ $\mathrm{m}$ uniform grid, were choose for each treatment (CP35 and CR30), totaling approximately one hectare per plot. However, point 3 of CP35 were eliminated from the study due to the impossibility of collections, resulting in eight evaluation points in the area with preserved Caatinga vegetation. Soil samples were collected from the $0-0.2 \mathrm{~m}$ layer because it is the agricultural layer, which has the highest nutrient concentrations, the greatest contribution of TOC, and presents a barrier zone within a few centimeters of depth. The sampling points were georeferenced and their coordinates were used to perform the spatial distribution of the TOC through geostatistics, using the Sigma Plot $\AA$ program (version 10.0). Four collections were carried out from February 2016 to April 2017 to represent the different compositions of the Caatinga biome over time. The soil samples were collected in hermetic bags and sent to the Laboratory of Soil Management of the UFC for determination of TOC, 
according to the Walkley-Black methodology modified by Yeomans and Bremner (1988).

\section{Temporal stability analysis}

Nonparametric Spearman's test and mean relative difference (MRD) were used to assess the TOC temporal stability. The Spearman's test was performed according to Equation 1 (ÁVILA et al., 2010):

$$
T=\frac{c S}{\sqrt{\operatorname{var}(c S)}}
$$

where:

$c s$ : is the Spearman's correlation coefficient; and var (cs): is the variance of the Spearman's correlation coefficient

The Spearman's correlation coefficient (cs) evaluates the correlation of the variable with the different sampling periods and was obtained using Equation 2; the variance of the correlation coefficient was obtained using Equation 3 :

$$
\begin{aligned}
& c s=1-\frac{6 x \sum_{i=1}^{N}(F i-f i)^{2}}{N^{3}-N} \\
& \operatorname{var}(c s)=\frac{1}{N-1}
\end{aligned}
$$

where:

$f i$ is the temporal position in the historical series;

$F i$ is the position in which the observations associated with $f i$ occupy in the historical series, in ascending order; and

$N$ is the amount of data in the historical series;

The relative difference was calculated according to Equation 4 (VACHAUD et al., 1985)

$$
\delta i j=\frac{T O C i j-\overline{T O C j}}{\overline{T O C \bar{j}}}
$$

where:

$\delta i j$ is the relative difference in position $i$ in time $j$;

TOC $i j$ is the value of soil total organic carbon content in position $i$ and time $j$; and $\overline{T O C j}$ is the average soil total organic carbon content, at all positions, in time $j$.

The average soil TOC at all positions in time $j$ was calculated using Equation 5, and for each position $i$, the mean and standard deviation of the relative difference were given by Equations 6 and 7, respectively:

$$
\begin{aligned}
& \overline{T O C} \bar{j}=\sum_{i=1}^{N} \text { TOC } i j \\
& \overline{\delta i}=\frac{1}{M} \sum_{J=1}^{M} \delta i j \\
& \sigma(\delta i)=\sqrt{\frac{1}{M-1} \sum_{j=1}^{M} \delta i j}
\end{aligned}
$$

According to Vachaud et al (1985) and Brocca et al. (2009), a small or nonexistent variation of $\delta i j$ over time, for each position $i$, indicates temporal stability, while low values of $\sigma(\delta i)$ indicate a stable position over time. Positive values of $\bar{\delta}_{l}$ indicate sites with higher TOC content than the local average, and negative values represent lower TOC than the average. The method of Zhao et al. (2010) and Penna et al. (2013) was used to find a representative point in the area, given by the temporal stability index (TSI), which was calculated using Equation 8.

$T S I C i=\sqrt{\overline{\delta i} i^{2}+\sigma(\delta)^{2}}$

Low TSI values indicate sites of high temporal stability of TOC, and high TSI values indicates sites of low stability over time.

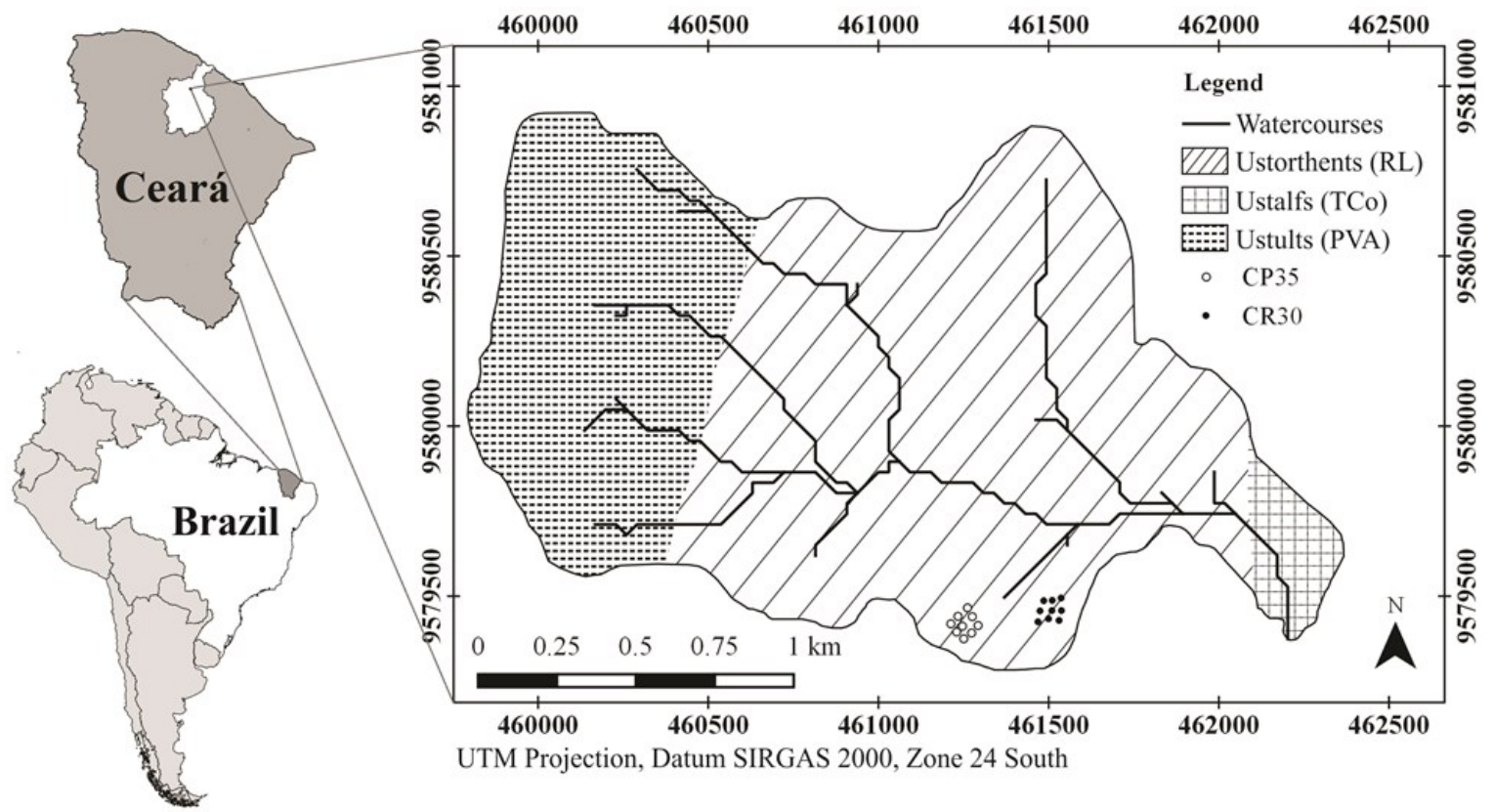

Figure 1. Location of the experimental area in a watershed of the Curu River Valley, in Pentecoste, state of Ceará, Brazil and distribution of sampling points. CP35 $=35$-year preserved area; CR30 $=30$-year pasture area.

Rev. Caatinga, Mossoró, v. 32, n. 3, p. 760 - 768, jul. - set., 2019 


\section{RESULTS AND DISCUSSION}

The temporal evolution of TOC in the two experimental areas presented a greater interquartile amplitude of the data for CR30 area in the May collection (Figure 2), and a greater variability in the CP35 area was found in the April collection. Considerable symmetry was found in all collection times in both areas. The highest mean TOC levels were mostly found in CP35, except in the February collection, in which higher values were found in CR30.

The TOC contents were higher in the two areas in the collection of May when compared to the first period, representing the highest levels of carbon in both areas, although it had no statistical difference in CR30 over time (Table 1).

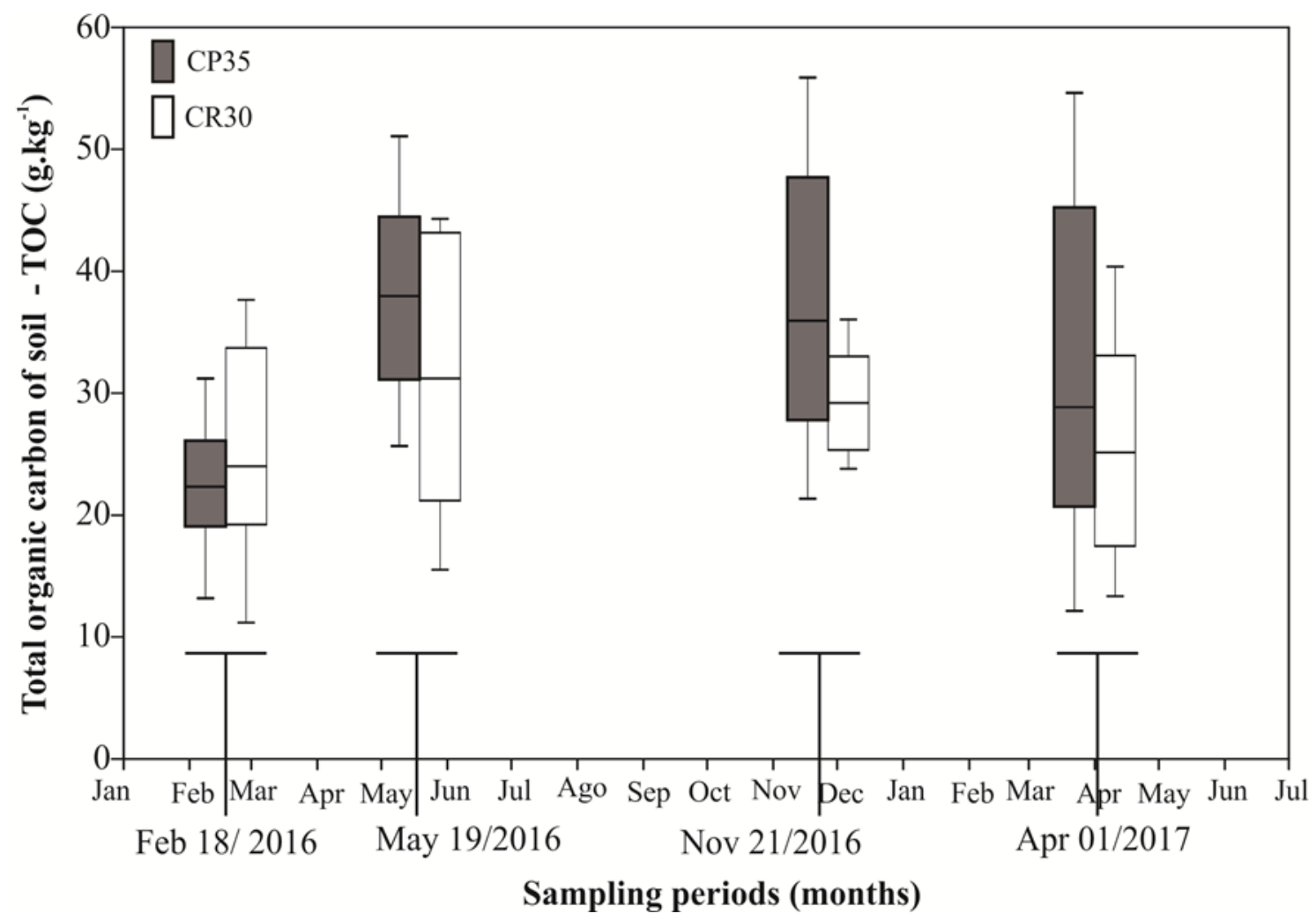

Figure 2. Total organic carbon (TOC) of soils under different uses in areas with Caatinga vegetation, in four sampling periods. CP35 = 35-year preserved area; CR30 $=30$-year pasture area.

Table 1. Mean, standard deviation $(\Sigma)$, and coefficient of variation (CV) of TOC contents in soils under different uses in the Caatinga biome.

\begin{tabular}{|c|c|c|c|c|}
\hline \multicolumn{5}{|c|}{ CR30 (TOC g kg-1) } \\
\hline Parameter & $02 / 18 / 2016$ & $05 / 19 / 2016$ & $11 / 24 / 2016$ & $04 / 01 / 2017$ \\
\hline Mean & $24.01^{\mathrm{ns}}$ & $31.21^{\mathrm{ns}}$ & $29.21^{\mathrm{ns}}$ & $25.13^{\mathrm{ns}}$ \\
\hline$\Sigma$ & 8.81 & 10.92 & 4.35 & 8.77 \\
\hline $\mathrm{CV}$ & 0.34 & 0.34 & 0.15 & 0.34 \\
\hline \multicolumn{5}{|c|}{ CP35 (TOC g kg $\left.{ }^{-1}\right)$} \\
\hline Parameter & $02 / 18 / 2016$ & $05 / 19 / 2016$ & $11 / 24 / 2016$ & $04 / 01 / 2017$ \\
\hline Mean & $22.41^{\mathrm{a}}$ & $37.96^{\mathrm{b}}$ & $34.45^{\mathrm{c}}$ & $29.67^{\mathrm{a}}$ \\
\hline$\Sigma$ & 5.53 & 8.79 & 10.16 & 13.15 \\
\hline $\mathrm{CV}$ & 0.25 & 0.23 & 0.32 & 0.46 \\
\hline
\end{tabular}

*Means followed by the same letter do not differ by the Tukey's test $(p \leq 0.05)$. Ns $=$ not significant.

This increase in TOC can be attributed to the vegetation dynamics of the Caatinga biome due to loses of leaves at the end of the rainy season-a strategy to reduce evapotranspiration rates (ALVES et al., 2006). This is corroborated by the results of Lopes et al. (2009) who found the highest values of monthly litter production in soils of Caatinga biome at the end of the rainy season. The increase of plant material on the soil tends to increase soil TOC, thus, increasing the soil carbon stock until it is fully decomposed and a new decrease in TOC contents begins. This could be observed in the results of the February collection, which coincided with the restart of the rainy season. 

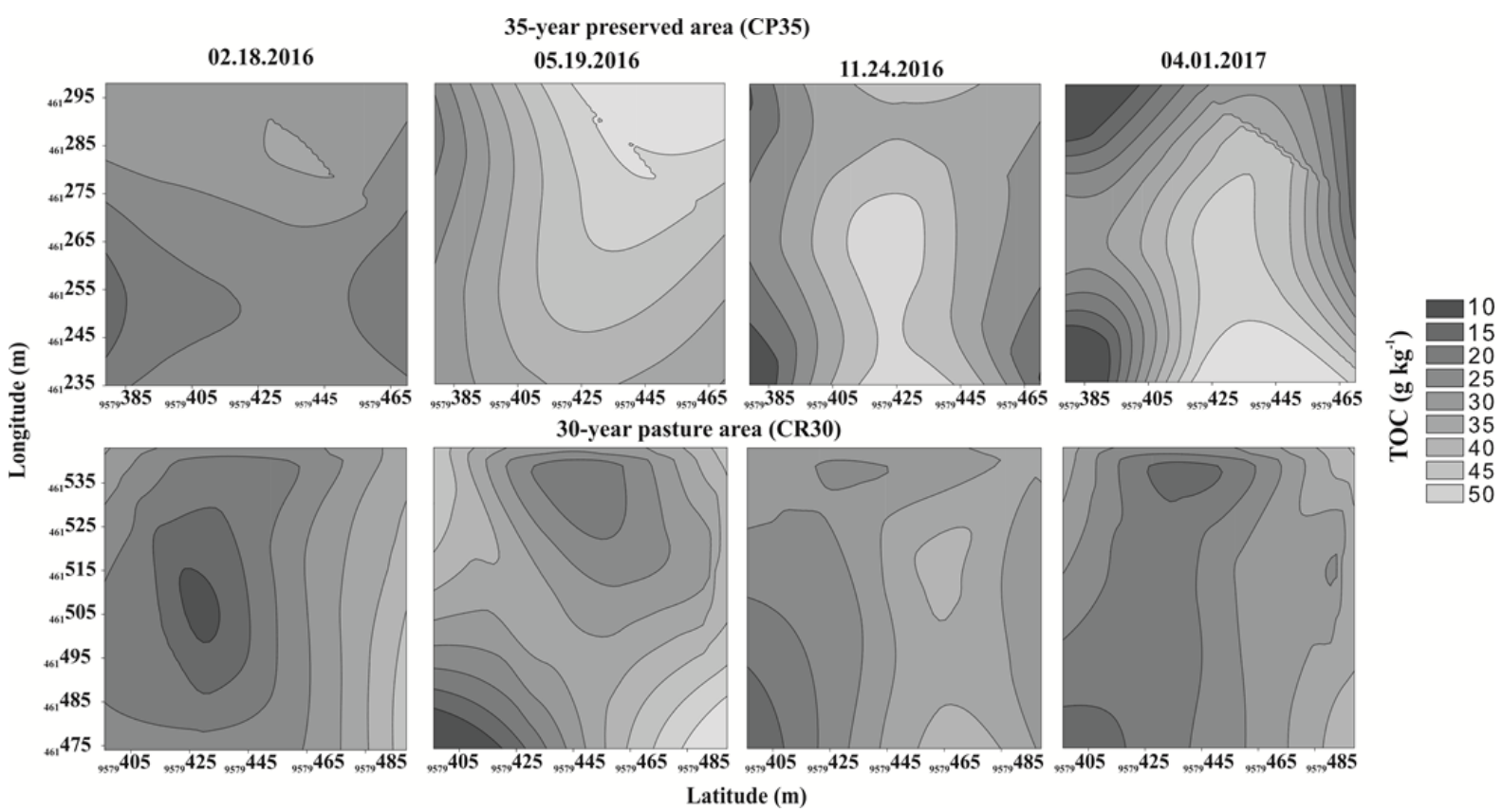

Figure 3. Spatial distribution of total organic carbon of soils under different uses in the Caatinga biome, in different sampling periods. CP35 = 35-year preserved area; CR30 $=30$-year pasture area.

The spatial distribution variation (Figure 3) showed a greater variability of TOC contents in the preserved Caatinga vegetation area (CP35) over time. This can be attributed to the greater complexity of the input and output of carbon in the system. The diversity of species and successional stage of vegetation are factors that influence the contribution of plant material to the soil (PEREIRA et al., 1989;
SUNDARAPADIAN; SWAMY, 1999). In addition, the presence of plant species with larger crown and consequently larger leaf area is more common in areas with preserved Caatinga vegetation (AMORIM et al, 2005).

The temporal analysis of the data through the Spearman's correlation test is shown in Table 2.

Table 2. Spearman's correlation coefficient matrix and P-test for total organic carbon content in soils under different uses in the Caatinga biome, in different sampling periods.

\begin{tabular}{|c|c|c|c|c|c|c|}
\hline & \multicolumn{2}{|c|}{ 05/19/2016 } & \multicolumn{2}{|c|}{$11 / 24 / 2016$} & \multicolumn{2}{|c|}{$04 / 01 / 2017$} \\
\hline & (CP35) & (CR30) & (CP35) & (CR30) & (CP35) & (CR30) \\
\hline $02 / 18 / 2016$ & 0.48 & 0.55 & 0.48 & 0.40 & 0.19 & 0.70 \\
\hline $\mathrm{P}$ & 0.21 & 0.11 & 0.21 & 0.26 & 0.62 & 0.03 \\
\hline $05 / 19 / 2016$ & & 1.00 & 0.67 & 0.48 & 0.31 & 0.82 \\
\hline $\mathrm{P}$ & & & 0.05 & 0.17 & 0.48 & 0.01 \\
\hline $11 / 24 / 2016$ & & & 1.00 & 1.00 & 0.67 & 0.73 \\
\hline $\mathrm{P}$ & & & & & 0.04 & 0.02 \\
\hline
\end{tabular}

There are no significant relationships between pairs of variables in the correlation table for $\mathrm{P}$ values $(p \geq 0.05)$. CP35 $=35$ year preserved area; CR30 $=30$-year pasture area

The Spearman's coefficient demonstrates the correlation of soil carbon in a given spatial position with different sampling times; a correlation closer to 1 indicates a greater temporal stability of the process (ÁVILA et al., 2010). CP35 presented a significant correlation between the November and April data, which represents the period of low plant material that will be decomposed and will give rise to TOC (November), and the restart of the high production of organic matter by the Caatinga vegetation (April).

CR30 had a greater temporal stability of the data, represented by a greater number of correlations (Table 2). These results are attributed to the lower diversity of plant species in the area and, therefore, a more uniform carbon input and loss, showed by the predominance of herbaceous and shrub vegetations in the area due to the higher incidence of solar radiation (AQUINO et al., 2018). According to Nascimento et al. (2013), large tree size with welldeveloped canopies may be more important to litter production over time, which is not observed in CR30 because of its not advanced successional stage.

The TOC stability over time was also evaluated through the data of relative difference between the two experimental areas. The 2, 4, and 5 sampling points of the CR30 presented means close to zero (Figure 4), indicating good temporal stability and relatively low coefficients of variation (Figure 
5); and CP35 did not present values close to zero.

Considering the two evaluated managements of the Caatinga vegetation, a greater temporal stability is found for CR30, confirming a greater uniformity of TOC in this area.

The variation of the mean relative difference and its standard deviation at the sampling points are shown in Figure 5.

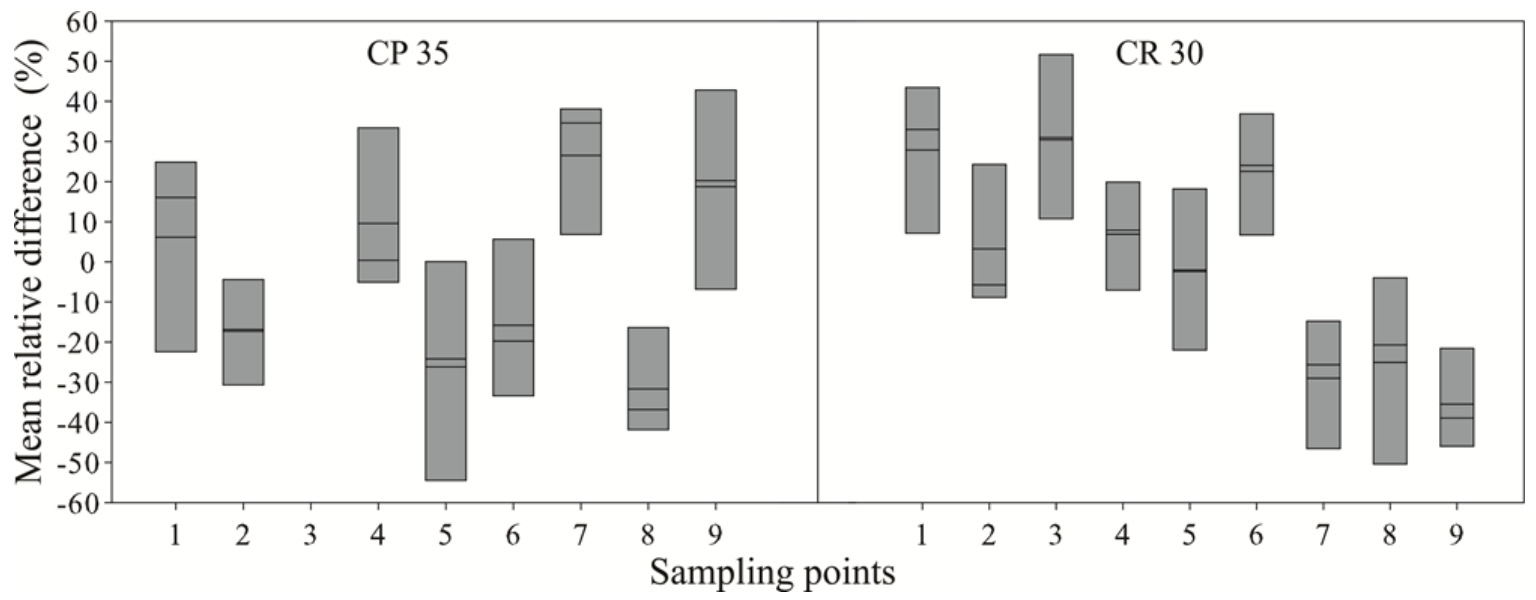

Figure 4. Boxplot of the mean relative difference in total organic carbon content in each sampling point of soils under different uses in the Caatinga biome. CP35 $=35$-year preserved area; CR30 $=30$-year pasture area.

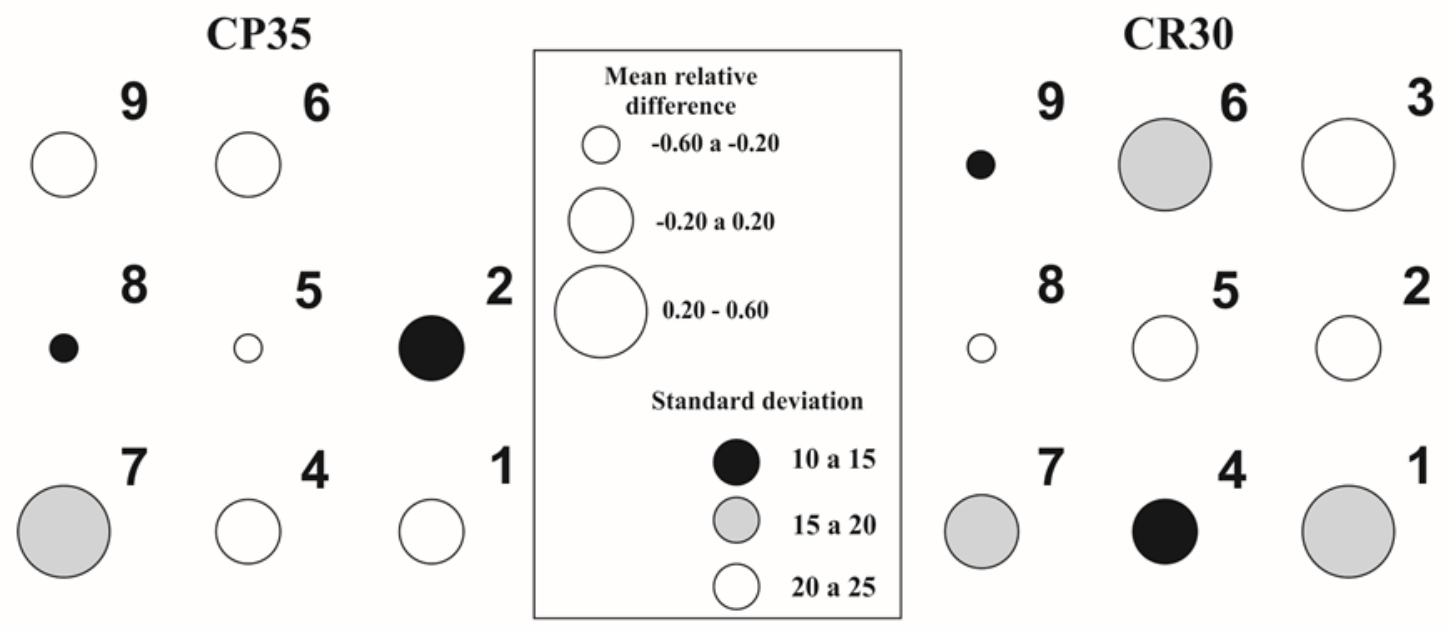

Figure 5. Distribution map of the mean relative difference and standard deviation for total organic carbon content in each sampling point of soils under different uses in the Caatinga biome. CP35 $=35$-year preserved area; CR30 $=30$-year pasture area.

CP35 presented more sampling points with mean relative difference closer to zero $(-0.20-0.20)$ than CR30; however, both areas presented the same number of points with the lowest standard deviation. The points with positive values represented areas with TOC contents above the average of the studied area, and negative values represented areas with lower TOC than the average of the area. The search for representative points of the area considered points with greater proximity to the average of the area and lower deviation, and the temporal stability index, whose distribution are shown in Figure 6. 

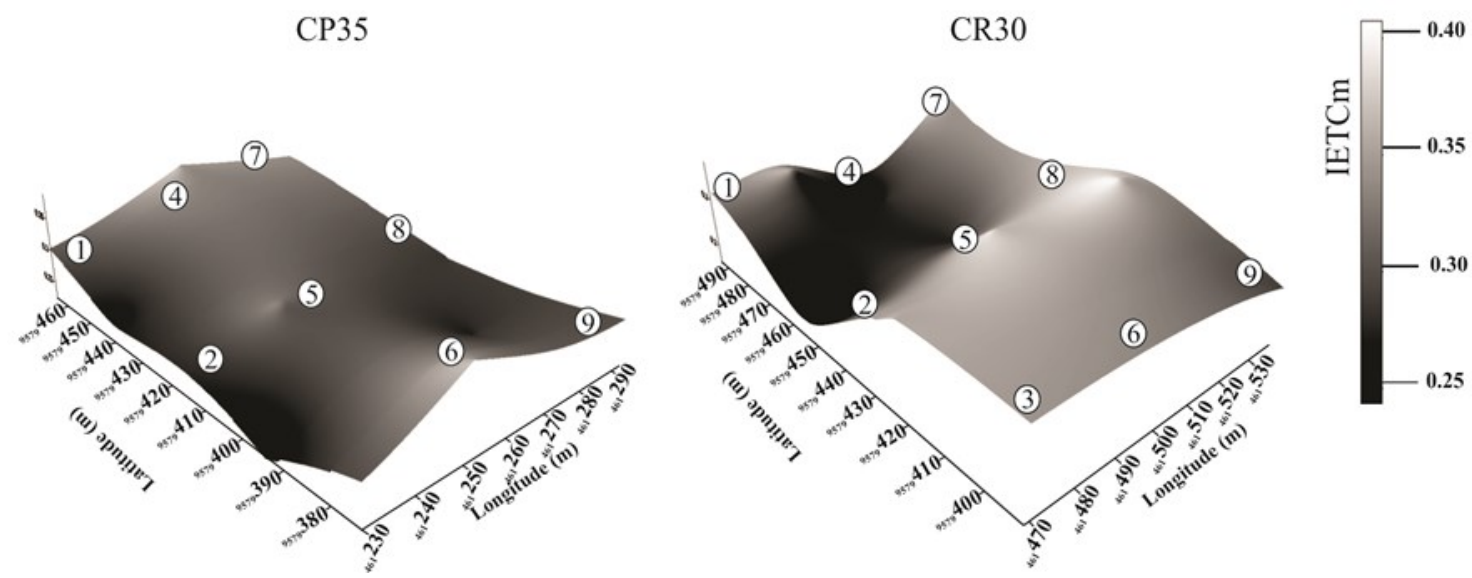

Figure 6. Spatial distribution of the temporal stability index (TSI) of carbon for each sampling point of soils under different uses in the Caatinga biome. CP35 $=35$-year preserved area; CR30 $=30$-year pasture area.

The 2, 4, and 5 sampling points of the CR30 showed the lowest carbon TSI values. Therefore, they are the best suited points to be used in the monitoring of the area because they present a higher temporal stability of carbon. The points in CP35 presented a more uniform distribution of the carbon TSI values; it was not possible to identify the lowest values of carbon TSI that could be selected as representative points for this area.

Penna et al. (2013) used carbon TSI to evaluate soil moisture and found lower values than those found in the present study, denoting a lower stability for TOC than for soil moisture when using the carbon TSI. This lower stability can be attributed to many factors that determine the TOC dynamics; their analysis would lead to a greater instability of the data over time.

CR30 presented greater temporal stability of soil TOC content than CP35. This was shown by the Spearman's correlation coefficient, which presented higher correlations between the collection times for CR30 and showed points with higher carbon TSI, which can be extrapolated to the analyzed area. Piotrowska-Długosz et al. (2017) evaluated the temporal stability of a data set and found no clear change associated with time, using Spearman's correlations; the greatest temporal stability of TOC was found for an agricultural area, which makes TOC deposition and degradation more homogeneous. It was also pointed out by OU et al. (2017), who found a significant correlation between natural and human factors in the formation of spatial patterns of TOC and attributed it mostly to anthropogenic disturbances.

The temporal dependence for the TOC input in CR30 denotes the possibility of performing different managements based on its greater stability. The presence of representative points of the area shows the smaller number of samples required for its evaluation due to the greater temporal stability of TOC in this area.

\section{CONCLUSION}

The soil total organic carbon (TOC) of the Caatinga vegetation area under a 30-year pasture (CR30) has more temporal stability than that in the area with 35-year preserved Caatinga vegetation (CP35), presenting approximately 1.5-fold higher temporal stability index. The thinning of the vegetation in CR30 homogenized the soil TOC, whereas the fallow area, which were preserved, had greater heterogeneity. The different production and transfer of biomass in CR30, due to the predominance of herbaceous plants, generates a greater soil TOC homogeneity; and the predominance of larger plants and trees in the CP35 generates a more heterogeneous production and transfer of soil TOC.

\section{REFERENCES}

ALMEIDA, A. M. M. et al. Avaliação de carbono orgânico total em reservatório no semiárido - caso Pereira de Miranda. Revista Geonorte, v. 7, n. 26, p. 35-47, 2016.

ALVES, A. R. et al. Aporte e decomposição de serrapilheira em área de Caatinga, na Paraíba. Revista de Biologia e Ciências da Terra, v. 6, n. 2 , p. 194-203, 2006.

AMORIM, I. L. et al. Flora e estrutura da vegetação arbustivoarbórea de uma área de caatinga do Seridó, RN, Brasil. Acta Botânica Brasilica, v. 19, n. 4, p. 615-623, 2005.

AQUINO, D. D. N. et al. Nutrient cycling and $\mathrm{CO}_{2}$ emissions in areas of preserved and thinned caatinga. Revista Árvore, v. 41, n. 3, p. e410308, 2018.

ÁVILA, L. F.; MELLO, C. R.; SILVA, A. M. da. Estabilidade temporal do conteúdo de água em três 
condições de uso do solo, em uma bacia hidrográfica da região da Serra da Mantiqueira, MG. Revista Brasileira de Ciência do Solo, v. 34, n. 6, p. 20012009, 2010.

BARRETO, H. F. M. et al. Impactos ambientais do manejo agroecológico da caatinga no Rio Grande do Norte. Pesquisa agropecuária brasileira, v. 45, n. 10, p. 1073-1081, 2010.

BROCCA, L. et al. Soil moisture temporal stability over experimental areas in Central Italy. Geoderma, v. 148, n. 3-4, p. 364-374, 2009.

COPPOLA, A. et al. Average moisture saturation effects on temporal stability of soil water spatial distribution at field scale. Soil Tillage Rescearch, v. 114, n. 2, p. 155-164, 2011.

COSTA, C. A. G. et al. Spatial behaviour of soil moisture in the root zone of the Caatinga biome. Revista Ciência Agronômica, v. 44, n. 4, p. 685694, 2013.

FIORIO, P. R. et al. Diferenciação espectral de solos utilizando dados obtidos em laboratório e por sensor orbital. Bragantia, v. 69, n. 2, p. 454-466, 2010.

FREITAS, C. A. S. de. et al. Produção de matéria seca e trocas gasosas em cultivares de mamoneira sob niveis de irrigação. Revista Brasileira de Engenharia Agrícola e Ambiental, v. 15, n. 11, p. 1168-1174, 2011.

GAO, L.; SHAO, M. Temporal stability of soil water storage in diverse soil layers. Catena, v. 95, n. 1, p. 24-32, 2012.

GENÚ, A. M.; DEMATtê, J. A. M. Espectorradiometria de solos e comparação com sensores orbitais. Bragantia, v. 71, n. 1, p. 82-89, 2012.

HOFFMANN, U. et al. Soil organic carbon in the rocky desert of northern Negev (Israel). Journal of Soils and Sediments. v. 12, n. 6, p. 811-825, 2012.

IBRAHIM, H. M.; HUGGINS, D. R. Spatiotemporal patterns of soil water storage under dryland agriculture at the watershed scale. Journal of Hydrology, v. 404, n. 3, p. 186-197, 2011.

LI, P. H. et al. Soil organic carbon stock is closely related to aboveground vegetation properties in coldtemperate mountainous forests. Geoderma, v. 154, n. 3 , p. $407-415,2010$.

LOPES, J. F. B. et al. Deposição e decomposição de serapilheira em área da Caatinga. Revista Agro@mbiente On-line, v. 3, n. 2, p.72-79, 2009.

MARTIN, M. P. et al. Spatial distribution of soil organic carbon stocks in France. Biogeosciences, v. 8, n. 5 , p. $1053-1065,2011$

MU, L. et al. Using the DNDC model to compare soil organic carbon dynamics under different crop rotation and fertilizer strategies. Spanish Journal Of Agricultural Research, v. 12, n. 1, p. 265-277, 2014.

NASCIMENTO, A. F. J. et al. Quantificação de serapilheira em diferentes áreas sob fragmentos do Parque Nacional Serra de Itabaiana, Sergipe. Ciências Agrárias, v. 34, n. 6, sup., p. 3271-3284, 2013.

OU, Y. et al. Spatio-temporal patterns of soil organic carbon and $\mathrm{pH}$ in relation to environmental factors-A case study of the Black Soil Region of Northeastern China. Agriculture, Ecosystems \& Environment, v. 245, n. 1, p. 22-31, 2017.

PENNA, D. et al. Soil moisture temporal stability at different depths on two alpine hillslopes during wet and dry periods. Journal of Hydrology, v. 477, n. 1, p. 55-71, 2013.

PEREIRA, R. M. A. et al. Estudos fenológicos de algumas espécies lenhosas e herbáceas da caatinga. Revista Ciência Agronômica, v. 20, n. 2, p. 11-20, 1989

PIOTROWSKA-DŁUGOSZ, A. et al. Spatiotemporal variability of soil sulfur content and arylsulfatase activity at a conventionally managed arable field. Geoderma, v. 295, n. 1, p. 107-118, 2017.

SANTOS, H. G. dos et al. Sistema Brasileiro de Classificação de Solos. 5. ed. Brasília, DF: Embrapa, 2018. 590 p.

SAMPAIO, E. V. S. B. Overview of the Brazilian Caatinga. In: BULLOCK, H. A; MEDINA, E. (Eds.) Seasonally dry tropical forest. Cambridge: Cambridge University press, 1995. v. 1, cap. 3, p. 35 $-63$

SAMPAIO, E. V. S. B. et al. Impactos ambientais da agricultura no processo de desertificação no Nordeste do Brasil. Revista de Geografia, v. 22, n. 1, p. $90-112,2005$.

SUNDARAPADIAN, S. M.; SWAMY, P. S. Litter production and leaf-litter decomposition of selected 
tree species intropical forests at Kodayar in the Western Ghats, India. Forest Ecology and Management, v. 123, n. 2-3, p. 231-244, 1999.

VACHAUD, G. et al. Temporal stability of spatially measured soil water probability density function. Soil Science Society American Journal, v. 49, n. 4, p. $822-827,1985$.

VAN WESENBEECK, I. J.; KACHANOSKI, R. G. Spatial and temporal distribution of soil water in the tiled layer under a corn crop. Soil Science Society American Journal, v. 52, n. 2, p. 363-368, 1988.

VENTERIS, E. et al. Influence of management history and landscape variables on soil organic carbon and soil redistribution. Soil Science, v. 169, n. 11, p. 787-795, 2004.

WANG, S. F.; WANG, X. K.; OUYANG, Z. $\mathrm{Y}$.Effects of land use, climate, topography and soil properties on regional soil organic carbon and total nitrogen in the Upstream Watershed of Miyun Reservoir, North China. Jornal of Environ Science, v. 24, n. 3, p. 387-395, 2012.

WIESMEIER, M. et al. Estimation of total organic carbon storage and its driving factors in soils of Bavaria (southeast Germany). Geoderma Regional, v. 1, n. 1, p. 67-78, 2014.

YEOMANS, J.C.; BREMNER, J.M. A rapid and precise method for routine determination of organic carbon in soil. Communications in Soil Science and Plant Analysis, v. 19, n. 13, p. 1467 -1476, 1988.

ZHAO, Y. et al. Controls of surface soil moisture spatial patterns and their temporal stability in a semiarid steppe. Hydrological Processes, v. 24, n. 18, p. 2507-2519, 2010. 